\title{
A 40 YEAR RECORD IN AN ICE CORE FROM THE DUNDE ICE CAP, CHINA
}

\author{
(Abstract) \\ by \\ Wu Xiaoling \\ (Lanzhou Institute of Glaciology and Geocryology, Academia Sinica, \\ Lanzhou, Gansu, People's Republic of China) \\ and \\ Lonnie G. Thompson \\ (Byrd Polar Research Center, Ohio State University, \\ 125 South Oval Mall, Columbus, OH 43210, U.S.A.)
}

\begin{abstract}
A cooperative glacio-climatological ice-core drilling and analysis program, administered by LIGC and BPRC, has been carried out since 1984. The major objective of this study is to extract from the Dunde ice cap records of the general environmental conditions, which include drought, volcanic activity, moisture sources, glacier net balance and possibly temperature over the last 3000 years.

In 1984 a group of 18 Chinese scientists and an American scientist spent 6 weeks on the Dunde ice cap. The central objective of their research was to evaluate the potential of the ice cap to yield a lengthy ice-core climate record. Results of the 1984 field work and 1985 laboratory analysis are submitted here.

The Dunde ice cap $\left(38^{\circ} 96^{\prime} \mathrm{N}, 96^{\circ} 24.5^{\prime} \mathrm{E}\right)$ is located in the north-eastern section of the Tibet plateau, China. Its length is $10.9 \mathrm{~km}$; the width varies from 2.5 to $7.5 \mathrm{~km}$. The total area of the ice cap is $57 \mathrm{~km}^{2}$. A $16 \mathrm{~m}$ core was drilled at the first site, located on a flat part of the ice cap, $5150 \mathrm{~m}$ a.s.1. A $10.2 \mathrm{~m}$ ice core was drilled at the ice cap summit $(5300 \mathrm{~m})$. A series of shallow cores and $2 \mathrm{~m}$ pits were excavated at each of the two sites and in the lower section of the ice cap.
\end{abstract}

A mono-pulse radar unit was used to determine ice thickness. The ice thickness ranged between 94 and $167 \mathrm{~m}$, with an average thickness of $140 \mathrm{~m}$. Using a thermistor cable, minimum temperatures of $-9.1^{\circ}$ and $-9.5^{\circ} \mathrm{C}$ were measured in the $16 \mathrm{~m}$ hole and $10.2 \mathrm{~m}$ hole respectively. Microparticle analysis of the ice core from the Dunde ice cap revealed a very high dust content, on average $16 \times 10^{5}$ particles ( $\geqslant 0.63$ to $\leqslant 16 \mu \mathrm{m}$ in diameter) per $\mathrm{ml}$ of sample, i.e. 3-4 times higher than the microparticle content in the Quelccaya ice cap, Peru, and 100 times higher than in the core from Byrd Station, Antarctica. Oxygen-isotope content ranged between -12 and -14 per mil. Initially it was anticipated that the oxygen-isotope content would produce a more negative value in the Dunde ice cap. More work is required to explain the mechanism controlling $\delta^{18} \mathrm{O}$ variation in the ice core from the Dunde ice cap.

The microparticles, oxygen-isotope content, conductivity, and tritium measurements, together with stratigraphy, temperature and density, are presented in the figures. The 40 year net-balance record reconstructed from the ice-core and oxygen-isotope profile is in good agreement with data from precipitation and major temperature trends obtained for the last 30 years from Delingha meteorological station, which is located $160 \mathrm{~km}$ south-east of the ice cap. 